\title{
Nostalgics, thugs and psycho-killers: Neo-fascists in contemporary Italian cinema
}

Alfio Leotta, Victoria University of Wellington

\begin{abstract}
Neo-fascism played a crucial role in the Italian political panorama of the second half of the twentieth century. However, despite its importance, this political movement has been significantly underrepresented in contemporary Italian cinema. Italian cinema has been traditionally characterized by a strong political commitment and left-wing film-makers have often attempted to examine issues emerging from within groups close to their own political position. While Italian cinema is characterized by a proliferation of films that focus on left wing or communist heroes, neo-fascists have been systematically excluded from screen representation or confined to the roles of one-dimensional villains: either dangerous, anti-social thugs like in Teste rasate/Skinheads (Fragasso, 1993); leaders of coup d'état associated with the military like in La polizia ringrazia/Execution Squad (Vanzina, 1972) and Vogliamo i Colonnelli/We Want the Colonels (Monicelli, 1973)or vicious psycho-killers like in San Babila ore 20: Delitto inutile/San Babila 8pm (Lizzani, 1976). However, today, twenty years after 1989 and the collapse of ideologies, Italian film-makers have started a process of historical revision that goes beyond the simplistic opposition good versus evil. This tendency is particularly apparent in recent productions such asRomanzo Criminale/Crime Novel (Placido, 2005) and particularly Mio fratello è figlio unico/My Brother Is an Only Child (Luchetti, 2007) which, while avoiding to
\end{abstract}


justify or celebrate neo-fascist ideology, attempt to explore the sociocultural motivations that lie behind the political choice of Italian neo-fascists.

\author{
Keywords \\ neo-fascism \\ My Brother Is an Only Child \\ terrorism \\ Italian cinema \\ Strategia della tensione \\ ideology \\ communism
}

Neo-fascism played a crucial role in the Italian political panorama of the second half of the twentieth century. However, despite its importance, this political movement has been significantly underrepresented in contemporary Italian cinema. Italian film has been traditionally characterized by a strong political commitment and left-wing film-makers have often attempted to examine issues emerging from within groups close to their own political position (O’Leary 2006). While post-war Italian cinema was characterized by a proliferation of films that focused on left-wing heroes or celebrated the resistance against the old fascist regime, neo-fascism and neo-fascists were systematically excluded from screen representation until the late 1960s. The bombing of Piazza Fontana in 1969, the emergence of right-wing terrorist groups and the beginning of the strategia della tensione 
represented a turning point in the representation of neo-fascism. Since then Italian filmmakers have tried at once to investigate and capitalize on the spectacular potential of the deviant actions of neo-fascist thugs and neo-fascism began to feature more regularly in Italian genre films, particularly commedie all'italiana, poliziotteschi and exploitation movies. In these genre films neo-fascists were still confined to the roles of onedimensional villains: either grotesque leaders of coup d'état associated with the military as in Vogliamo i colonnelli/We Want the Colonels (Monicelli, 1973), anonymous killers as in La polizia ringrazia/Execution Squad (Vanzina, 1972) or dangerous, anti-social thugs as in I ragazzi della Roma violenta/The Children of Violent Rome (Savino, 1976).

However, today, twenty years after 1989 and the collapse of traditional political ideologies Italian cinema has started a process of historical revision that goes beyond the simplistic opposition good versus evil. This tendency is particularly apparent in recent productions, most notably Mio fratello è figlio unico/My Brother is an Only Child (Luchetti, 2007) which, while avoiding to justify or celebrate neo-fascist ideology, attempt to explore the sociocultural motivations that lie behind the political choice of Italian neo-fascists.

While a large number of recent studies have dealt with both the relation between fascism and cinema and the representation of fascism in contemporary Italian cinema (Zagarrio 2004, 2009; Zinni 2010), little attention has been dedicated to the analysis of cinematic representations of neo-fascism. This article will attempt to fill this gap in the existing literature by providing the first analysis of the representation of neo-fascist characters in a selected number of contemporary Italian feature films. 1 
I will start by sketching a brief outline of the history and ideological development

of the neo-fascist movement in Italy. I will then move onto the historiographic overview of the representation of neo-fascism in Italian cinema. I will focus in particular on the way in which during the 1970 s the cinematic construction of neo-fascists was deeply influenced by genre conventions that in turn confined right-wing militants to marginal narrative roles. The main case studies will be the commedia all'italiana, the poliziottesco and exploitation movies. The article will be concluded by the analysis of the impact of significant political events such as the fall of communism and the Mani Pulite scandal on more recent cinematic representations of neo-fascism such as My Brother Is an Only

Child.2

\section{The Italian Republic and the emergence of neo-fascism}

The post-war period in the new Italian Republic was marked by deep social, cultural and political divisions apparent in the struggle for power between the Christian Democratic Party and the Italian communists (Ginsborg 1989). During the late 1940s, after the political purges that characterized the end of the war and the disintegration of the fascist regime, another faction slowly emerged in the Italian political panorama: the Movimento Sociale Italiano (MSI). The MSI was the most important and most visible expression of a new political movement defined as 'neo-fascism'.

According to James Gregor the term neo-fascism emerged after 1945 and was used to identify all the individual and political groups that inherited the political, cultural and moral legacy of the fascist regimes that had been defeated at the end of World War II 
(2006: 54).3 Neo-fascist movements allowed the former fascist elite that had survived the war, the possibility to operate within the new democratic Italy. However, Italian neofascism rejected the new global order that emerged from Yalta and was, by its very nature, excluded from any possibility of alliance with the political formations that had written the new Italian constitution. The ideological radicalization of the movement, coupled with the democratic anti-fascist foundations of the new Italy, determined the political marginalization of neo-fascism (Chiarini 1995). During the first stages of its life, Italian neo-fascism attempted to regroup former fascist supporters around the mystique of a pure fascism that resolutely refused to compromise with the dominant political forces of the time. Thus Giano Accame, one of the founders of the MSI, describes the first years of Italian neo-fascism:

During the first few years of its existence the MSI was a party that regrouped veterans and young boys who wished they had participated to the war; a party loyal to dream of the lost Empire and opposed to traitors and turncoats; a party of people who standing among ruins did not realize they belonged to a world that did not exist any longer. (1996: 50)4

Italian neo-fascism presented itself as a movement of 'internal exiles' opposed to everything and everybody: both the communist east and the capitalist west. However, the ideological premises of Italian neo-fascism were marked by a profound ambiguity. On the one hand, Italian neo-fascism proclaimed itself a fierce enemy of the values, culture 
and myths of western capitalism and consumerism (often equated to the United States), on the other hand the very survival of a strong neo-fascist movement was dependent on its support to American, democratic and western politics, which in turn would guarantee its legal existence. Italy's geopolitical position, at the border between the eastern and the western block, determined the so called 'Italian anomaly', the strong development of radical movements at the two ends of the political spectrum. The growth of the PCI,5 the biggest European communist party of the post-war era, was paralleled by the expansion of the MSI, Europe's largest far right movement. Both political forces gave voice to growing feelings of dislocation and discontent in certain sectors of the Italian population (the MSI reflecting the dissatisfaction of the economically depressed areas of the south). This tendency reached its apex in the general election of 1972 when the PCI gained 27 per cent of the votes while the MSI obtained almost 9 per cent (Ignazi 2006: 39). The expansion of a strong anti-communist party, able to effectively contrast the communist dominance on the streets favoured, directly and indirectly, the political agenda of the DC.6 In open contrast with the grassroots of the party, the elite of the MSI gradually developed a more moderate, pro-American political line in an attempt to establish a dialogue with the majority party, the DC.7 Neo-fascist militants played a crucial role in the strategia della tensione, the attempt to establish an authoritarian government in Italy through bombings and other violent attacks, supporting the activities of institutions such as Gladio, a network of anti-left terror that was funded by both the United States and exponents of the Italian moderate government. 
Other smaller neo-fascist groups such as Avanguardia Nazionale, Ordine Nuovo and Terza Posizione gradually emerged forming along with the MSI, a complex neofascist universe. Since the outset the neo-fascist movement was characterized by contradicting tendencies and currents of thought, conflicting myths and symbols. The celebration of the fascist era often coexisted with the adoption of the symbols and ideas of other fascist regimes such as Hitler's Nazism, the Spanish Falange and the Rumanian Iron Guard. A left-wing neo-fascism influenced by Mussolini's socialism and the antiimperialism of movements for national independence is often at odds with a right-wing

neo-fascism characterized by religious fundamentalism and traditionalism. The common element to the different neo-fascist currents is the reference to the fascist past and, in particular, a nostalgic pessimism that is reflected in the work of the main theorist of Italian neo-fascism, Julius Evola. According to Evola mankind is currently living in the Kali Yuga, a dark age of unleashed materialistic appetites, spiritual oblivion and organized deviancy whose most obvious symptoms are the triumph of communism, consumerism and democracy (1998).8 Evola claims that the only way to escape the decadence and corruption that affects the modern world (epitomized by the fall of the fascist regimes) is the radical opposition and rejection of modern values. Evola's ideas contributed to the political isolationism of Italian neo-fascism that in turn resulted in the refusal to compromise with the democratic institutions of post-war Italy and the justification of violent or terrorist actions.

\section{Italian cinema and neo-fascism}


The modus operandi of neo-fascist terrorism was mainly characterized by unclaimed bombings that often killed dozens of victims as in Piazza Fontana in 1969 or at the Bologna Train Station in 1980. According to some commentators (Pergolari 1997; Glynn et al. 2010) the anonymity and invisibility of its perpetrators has made neo-fascist terrorism elusive in terms of both memory and representation. Because of its obscure nature neo-fascist terrorism poses a formal, as well as a political problem to Italian filmmakers (Glynn et al. 2010: 18). However, the causes of the underrepresentation of neofascists in Italian cinema are also explained by a number of other factors.

First of all, the political marginalization of the neo-fascists. Even though the popular support to neo-fascist movements reached significant dimensions particularly in the 1960s and 1970s, the neo-fascists were consistently excluded from the political system, and with the exception of the short parenthesis of the Tambroni cabinet, they never participated in any Italian government since the formation of the republic in 1947.9 Neo-fascists were confined to a political and cultural ghetto and for decades represented an enigma for Italian intellectuals, particularly film-makers, which simply ignored the codes, symbols and myths of this political movement. In line with the Gramscian theory of cultural hegemony, Italian communists saw the realm of culture as a vital sphere in the construction and maintenance of the social order and Marxist hegemony is particularly apparent in Italian cinema since the emergence of neo-realism (Gundle 2000; Fantoni Minnella 2004; Bisoni 2009). The political commitment of Italian cinema is reflected in the attention to history and the celebration of the anti-fascist resistance. Fascism and Nazism are the subjects of neo-realist films such as Roma città aperta/Rome Open City 
(Rossellini, 1945) produced in the immediate post-war period. The early 1960s are characterized by a proliferation of films about Fascism with more than 40 productions released in the period between 1960 and 1963 focusing on war, the Resistance and Mussolini's regime. Lino Miccichè Micciché thus explains the popularity of films about Fascism during this particular period:

Films about Fascism provided the Italian petit bourgeois with an opportunity to get rid of their guilt and create the illusion of a vicarious participation to the heroic period of the anti-fascist resistance. (1980: 40)10

Paradoxically, while Italian film-makers have frequently been interested in analysing the genesis, psychology and memory of fascism, they have often neglected the investigation of post and neo-fascism. When Italian directors have attempted to tackle contemporary political issues they have rather preferred focusing on the analysis of left-wing heroes or anti-heroes. Left-wing terrorism during the 1970s represents a particularly problematic issue for politically committed film-makers. Drawing upon the work of R. Catanzaro (1991), A. O'Leary claims that the Italian revolutionary left has often faced the problem of reconciling the use of violence with the ideal of a violence-free society (2006). Leftwing film-makers have often attempted to understand the consequences of politically motivated violence emerging from within groups close to their own political position and, apart from some exceptions, they have avoided the examination of neo-fascism's history and psychology. Furthermore, as claimed by A. Pergolari, when Italian film-makers have 
ventured in the intricate and mysterious territory of neo-fascism the results have been disappointing both at the box office and among the critics (2007: 171). This tendency has recently been contradicted by the popular success of a film that largely focuses on a neofascist character, Daniele Luchetti's Mio fratello è figlio unico/My Brother Is an Only Child (2007).

From this point of view, a brief outline of the history of the representation of neofascism in Italian cinema will help to clarify the relation between My Brother Is an Only Child and the earlier tradition of films about neo-fascism. Furthermore, the examination of the treatment of neo-fascism in popular Italian film genres will allow the possibility to identify different modes of representation, each characterized by different thematic, narrative and formal concerns.

\section{Neo-fascism and comedy}

The late 1940s, 1950s and 1960s are characterized by the virtual absence of neo-fascists from Italian screens. When neo-fascists appeared they were often framed within a comical perspective. It is the case of films such as Toto Diabolicus (Steno, 1963) in which one of the characters, the General Scipione di Torrealta lives secluded in a villa called Il Littorale, surrounded by a number of servants who pretend to be fascists soldiers at his command. The General, played by Totò himself, dresses in fascist uniforms and performs the ritual execution of the mannequins of famous anti-fascists, including

Churchill and De Gaulle. His folly is played down by his assistant as harmless 'nostalgia of the good old times'. The grotesque character played by Totò is reminiscent of the 
Duke of Montalbano in Fellini's La Dolce Vita (1960). Marcello, the protagonist of the film, overhears the Duke, one of the guests at the party held at the castle of an old aristocrat, talking about his memories of Mussolini and the regime. The duke and other noblemen gathered at the castle are the symbols of a decadent upper class, the grotesque remnant of a dark era. Significantly the duke and the other guests participate to a ghost hunt, attempting in vain to reconnect with a past that is gone forever. The topos of the castle is an important feature of another comedy Anni Facili/Easy Years (Zampa, 1953) one of the first films to explicitly deal with the neo-fascist movement. The film tells the story of an anti-fascist professor who goes to Rome to obtain government approval on the production of a new medicine, but has to face the corruption of Italian bureaucracy. The protagonist works for a nobleman who is supported by a powerful group of former fascists who hide in a remote castle and lead their lives as if the fascist regime had never ended. In all these cases, the neo-fascists are rather 'postfascists', grotesque but, after all harmless and comical nostalgics, who live isolated from the rest of the world.

The 1970s represent an important shift in the representation of neo-fascism. Vogliamo i colonnelli/We Want the Colonels, directed in 1973 by Mario Monicelli is a commedia all'italiana that focuses extensively on the neo-fascist movement. We Want the Colonels captures well the paranoia that characterizes the early 1970s, a period characterized by the explosion of political violence on the street and the emergence of right-wing terrorism. The film is inspired by the failed coup d'état planned in December 1970 by Valerio Junio Borghese, a former fascist officer, with the support of neo-fascist militants and sections of the army.11 The film, whose title refers to the regime of the 
Greek colonels, is filled with references to the political events of the time. We Want the Colonels opens with the account of a terrorist attack of the Milan cathedral, an allusion to the bombing of Piazza Fontana, the event that marked the beginning of the strategia della tensione. The character of the Minister of Internal Affairs is inspired by Giulio Andreotti, one of the main exponents of the Christian Democrats, often accused of manipulating the actions of radical political groups for his party's benefit. We Want the Colonels manages to represent effectively the social complexity of the neo-fascist movement made up of uneducated sub-proletarians like Ciccio Introna, ruthless and corrupted businessmen like Irnerio Steiner and pathetic veterans like Colonel Vittorio Emanuele Ribaud.

The emergence of neo-fascist terrorism as a real socio political threat towards the end of the 1960s, influenced the treatment of the protagonists of the film. While the representation of the neo-fascists in earlier comedies was characterized by an underlying irony, We Want the Colonels is marked by a bitter sarcasm. In the film there are no likeable characters and all the neo-fascists are morally and physically corrupted. The colonels who participate to the coup are either obese, disfigured or decrepitly old. The names of some of the neo-fascists such as Colonel Bassi-Lega (base or vulgar) reflect their lack of moral values. Similarly, the female characters are either extremely ugly or nymphomaniacs.

The film develops one of the themes that was already hinted at in Easy Years, namely the ambiguous relationship between neo-fascism and the ruling political class of the time. In the film, in fact it is the majority party (the DC) to benefit from the failed coup d'état, capitalizing on the opportunity by reinforcing its own political position. The 
neo-fascists, are portrayed as grotesque, tragicomic, but ultimately ineffective characters. The leader of the group, Tritoni, often interrupts the plans for the coup distracted by the sexual advances of Colonel Bassi-Lega's daughter. The most significant force under Tritoni's order is a battalion of 200 foresters who attempt to approach Rome on old scooters. The neo-fascist militants themselves are painfully incompetent and unfit to combat like Ciccio Introna. The real villains, as the film suggests, are the majority party politicians who exploit the neo-fascists for their own political agenda. The minister of internal affairs Li Masi uses the failed coup as a pretext to dismantle the parliament and establish martial laws. Monicelli prophetically suggests how the threats to democracy coming from extreme right-wing forces were often linked to the secret services, Masonic lodges and powerful members of the government (Testa 2006).12

\section{Neo-fascism and poliziottesco}

A narrative structure in which white collars, exponents of the new democratic regime manipulate the neo-fascists for their own purposes reappears in different form in many films of the 1970s, particularly the cop films genre (poliziottesco). According to O'Leary (2010) and Pergolari (2007), cop films were particularly well equipped to translate on screen the strategies and paranoia generated by right-wing terrorism. The strategia della tensione represented a formal challenge for film-makers. According to O'Leary, in fact, while the psychological drama or the family saga have often provided effective means to represent the nature of left-wing terrorism, 'right-wing terrorism, because of its obscure and spectacular nature, seems to have required an often more extrovert means of 
depiction in the conspiracy mode' (2009: 49). The discovery of a conspiracy is a staple narrative component of these films. In the first Italian poliziottesco, La polizia ringrazia/Execution Squad (Vanzina, 1972), the protagonist of the film Inspector Bertone, has to deal with a far right group, 'Roma Pulita'/'clean Rome' that has engaged in the systematic elimination of ordinary criminals. The subversive goal of the paramilitary organization, which benefits from government protection and the support of wealthy industrialists group, is to bring about an authoritarian state. Subsequent films such as La polizia sta a guardare/Ransom! Police is Watching (Infascelli, 1973) or the more sophisticated Io ho paura/I Am Afraid (Damiani, 1977) are all concerned with the covert connection between the state and neo-fascist conspirators. Mary P. Wood explains the popularity of the conspiracy thrillers claiming that in a period of intense sociocultural transformations such as the 1960s and 1970s in Italy 'these films attempt to impose order on a world which is perceived as difficult to understand, complex, mysterious, controlled by people who mask their control behind commonsense assumptions, coercion, and ritual' (2003: 153).

In most of these films, however, the analysis of the neo-fascist characters is completely sacrificed to the narrative development. In the cop films and conspiracy thrillers of the 1970s right-wing militants are monodimensional characters, mysterious or sometimes invisible hit men who do not display any emotion and are dangerously ubiquitous. In Execution Squad the neo-fascists are organized in secretive and efficient execution squads that show no mercy to criminals and political opponents. The leader of the neo-fascist group, former police commissioner Stolfi, is a balanced individual and an 
eloquent orator able to seduce the media with anti-democratic rhetoric. The loud, grotesque, tragicomic neo-fascists that populated comedies Italian style such as We Want the Colonels, gave way to cold, efficient killers who hide their features behind thick sunglasses and dark coats.

\section{Neo-fascism and exploitation movies}

Towards the end of the 1970 s the characteristics of neo-fascist activism radically changed. The violence in the street was quickly escalating, the grassroots of the MSI were often disappointed with the official line of the party, in particular its indirect support of the Christian democratic government, and new neo-fascist groups such as Terza Posizione emerged. These new groups recruited the support of young activists and were extremely close to terrorist groups such as the N.A.R., which in turn decided to break with the traditional modes of neo-fascist terrorism that privileged bombings and anticommunism. The N.A.R. led by Giusva Fioravanti and Francesca Mambro escaped the control of the old MSI elite and made the headlines of Italian newspapers by targetting policemen and judges. Often ideology was only an excuse to perpetrate extreme acts of violence and crime. Several members of the N.A.R. were involved in bank robberies and murders in collaboration with non-political organizations.

In 1975 a group of neo-fascist militants raped, tortured and killed two young girls in the outskirts of Rome. This episode of crime influenced the emergence of a new stage in the representation of neo-fascism. In 1976 a number of exploitation movies such as San Babila ore 20: un delitto inutile/San Babila 8pm (Lizzani); I ragazzi della Roma 
violenta/The Children of Violent Rome (Savino) and I violenti di Roma bene/Terror in Rome (Grieco) were released in the Italian movie theatres. These films adopted a pseudodocumentary approach as they attempted to analyse the perverted personality of a small group of neo-fascist criminals. The three films engaged in a sociocultural portrayal of the symbols, ideas and background of the neo-fascists, in an effort to explain the recent wave of senseless neo-fascist violence. In these films the neo-fascists are young and wealthy, wear aviators, cowboy boots and despise the previous generations of fascists and neofascists. These films mark a shift in the representation of neo-fascists from violent champions of order and discipline to agents of chaos and perversion.

In The Children of Violent Rome the neo-fascists form a criminal gang that competes, emulates and is emulated by other ordinary criminal groups. In the film there is an attempt to sketch a political commentary on neo-fascists by highlighting their difference from ordinary criminals. The neo-fascists dress well, drive expensive cars and live in modern apartments decorated with Nazi and fascist memorabilia. While the criminal acts perpetrated by non-political gangs are somehow explained as the result of poverty, unemployment and social malaise, the crimes of the neo-fascists are motivated by boredom and pure sadism. However, often the political engagement of the film is subjugated to the spectacular representation of the criminal acts (violence and rape) with the risk of satisfying the voyeurism of the spectators and celebrate the sadism of the neofascist/criminals.

In all instances neo-fascist violence is connected to sexual perversion and deviance. The Children of Violent Rome opens with one of the neo-fascists, unable to 
gain pleasure from heterosexual relations, reaching orgasm by playing pinball in front of his friends. The girls in the neo-fascist group are either nymphomaniacs or masochistic, while the recurrent fantasy of the sadist leader of the group, Marco, is to attain orgasm while killing his sexual partner. Similarly, in San Babila 8pm one of the neo-fascists is impotent and can gain sexual pleasure only by beating up his sexual partner. The neofascists claim that violence and terrorist attacks are 'better than fucking' clearly displaying a sadist and deviant personality. In his analysis of films about Fascism and Nazism made in the 1960s and 1970s David Forgacs claims that in these texts there is an equation between sexual and political perversions as both threaten order by transgressing, disturbing and destabilizing. Drawing upon Susan Sontag, Forgacs claims that 'it is the repression of fascism from official memory that allows it to resurface, invested with erotic meanings, as fantasy, in the next generation' (1999: 221). In the case of The Children of Violent Rome and San Babila 8pm however, neo-fascism does not resurface from a forgotten past, but rather from an obscure section of society, the ghetto to which the movement had been confined since the end of the war.

\section{The 'death of ideologies' and My Brother Is an Only Child}

The season of terrorism, the years of lead, ended in the 1980s thanks to extraordinary measures taken by the Italian government. Terrorism had led to distrust in ideologies and to a growing indifference of the younger generations towards political life. At the same time the disintegration of the USSR in 1989 dramatically changed international relations. After the failure of communism and the disappearance of their main ideological reference 
most of the European communist parties, including the Italian one, were struggling. Furthermore, the sociocultural structure of the country was deeply modified by the emergence of private television broadcasters, political corruption scandals and large migratory influxes, originating mainly from northern Africa and Eastern Europe. After the disappearance of its main ideological opponent, communism, the neo-fascist movement shifted its focus on the battle against clandestine migration.

During the 1980s Italian neo-fascism was also influenced by the growing popularity of the skinhead movement that reached Italy fifteen years after its emergence in Great Britain. The Italian skinhead scene reproduced the original division between right-wing, left-wing and apolitical skinheads that characterized the original movement, however, the explosion of racially motivated acts of violence implied that neo-fascist and neo-Nazi skinheads gained more media exposure and soon stood for, in the eyes of the public opinion, the whole Italian skinhead subculture. Teste rasate/Skinheads, an exploitation movie directed in 1993 by Claudio Fragasso, attempted to capitalize on the curiosity of mainstream audiences towards the skinhead subculture. The film tells the story of Marco, an unemployed young man with no political views who lives in a slum in the outskirts of Rome. Marco decides to join the local neo-fascist skinhead gang and he is soon forced to commit acts of violence against Jews and migrants. However, one day after being wounded by his ex-girlfriend he is abandoned by his gang and left to die alone. While Skinheads is obviously influenced by another movie about neo-Nazi skinheads, Romper Stomper (Wright, 1992) released just one year earlier, it significantly differs from previous Italian films about neo-fascism. While in earlier films the 
ideological beliefs of the characters are always taken for granted and their motivations never explained, in Skinheads the events are seen from the perspective of the protagonist, a young proletarian with good intentions, who is first convinced of the goodness of neofascist ideals and subsequently betrayed by his own comrades who need his money to support an international right-wing organization. While in the past films operated an equation between the deviant personality of the neo-fascists and their flawed ideology, Skinheads separates the treatment of the individuals from the critique of ideology, the thesis of the film is that anybody could potentially become a neo-fascist. The film does not suggest a critique of neo-fascist personality (Saverio, the neo-Nazi leader is brave and friendly) rather it is the inhuman rigidity of the ideological machine to be under scrutiny. It is his attachment to ideology that causes Marco to lose his money, his mother and his girlfriend.

The 1980s and 1990s in Italy, like in the rest of Europe, were characterized by a deep distrust in ideologies and the old modes of political aggregation. The disappearance of the Communist Party implied that anti-communist political groups such as the neofascist MSI did not have any reason to exist any longer. At the beginning of the 1990s traditional political actors such as the Christian Democratic Party and the Communist Party had all disappeared. In 1994 Gianfranco Fini proposed the dissolution of the MSI and the creation of National Alliance (Alleanza Nazionale), a modern conservative party that rejected any association with the fascist past (Chiarini 1995). The very notion of political party was questioned the same year when Silvio Berlusconi created the Forza 
Italia movement that was programmatically opposed to the ideological character of traditional political parties.

After Skinheads neo-fascism and neo-fascists do not play any significant role in any Italian films for more than ten years until Michele Placido's Romanzo Criminale/Crime Novel (2005), a film inspired by the true story of the Banda della Magliana, a gang that dominated criminal activities in Rome during 1970s. The criminal organization collaborated with the secret services, the mafia and neo-fascist groups and was involved in the strategia della tensione. The film tells the story of the gang from the criminals' perspective attempting to explain the political, social and cultural reasons that led to their rise and fall. One of the members of the organization is Nero, a neo-fascist who joins the gang in order to fund the political activities of his group. Neo-fascism features more prominently in Daniele Luchetti's award winning and critically acclaimed Mio fratello è figlio unico/My Brother Is an Only Child (2007).

My Brother Is an Only Child tells the story of, Accio and Manrico, two siblings who drift apart as a result of the violent political atmosphere that characterizes Italy during the 1960s and 1970s. The rivalry that tears apart the two brothers is the metaphor of the socio-political conflicts that lacerated Italy during these two decades. Rather than focusing on historical events the film attempts to use the two main characters as metaphors of the different, conflicting attitudes and mindsets of the time. The characters are at the same time very human, credible but also stereotyped as each of them embodies a specific sector or class of Italian society. Manrico is the communist worker and activist; Violetta is the communist student, the parents, who resort to the use of the crucifix to 
sabotage a communist meeting and support Accio's decision to join the seminary, belong to the moderate silent majority, finally, Accio is a self-proclaimed fascist. All the spectrum of political positions is represented within the Benassi family. In recreating the microcosm of the political conflicts of the 1960s and 1970s Luchetti underlines the internal character of the political struggle that split the country in two. The crumbling house that is a constant theme throughout the film metaphorically represents Italy. The wounds inflicted to the country during the war have not healed yet as the process of reconstruction has been paralysed by the constant confrontation between the different ideologies that divide the country.

From this point of view the setting of the film is particularly meaningful. The movie, like the book on which is based, 13 is set in Latina one of the cities built by Mussolini according to the peculiar canons of fascist architecture.14 The representation of Latina as a decaying fascist town reveals how the imperial ambitions of Mussolini's regime were at odds with the poverty of the common people. Furthermore, the crumbling fascist architecture of the town is a powerful visual metaphor of Italy's inability to overcome the trauma and the divisions of World War II. Despite the divisions between the protagonists of the film there are not entirely negative characters. Even the neofascists are quite likeable characters. The spectator identifies with Accio and is somehow led to understand the reasons why he becomes a fascist. Mario Nastri the tablecloth seller is essentially a positive character. The very choice of the actor who plays Mario, Luca Zingaretti, supports this reading as his persona is often associated with positive roles. The nephew of the party leader plays table soccer with Accio like any other ordinary boy. In 
depicting the fascists as humans the film-makers imply that they were Italian too, part of the same family before being anything else. Even though in the film fascist ideology is often represented as outmoded and 'wrong' the spectator is led to understand how the fascist motivations were actually genuine. Luchetti's thesis here is that the fascist anger and their very existence was somehow a consequence of their exclusion from the political system. Accio is expelled from his bedroom and confined to a corner of the living room in the same way in which the MSI, the neo-fascist party, had been excluded and marginalized from the political debate.

My Brother Is an Only Child is a critical representation of the 1960s from a contemporary perspective. The film conveys a strong critique of the ideologies that have divided Italy and led to the terrorism years. The film is dotted with satirical comments on the role and the character of the ideology. During the film the fascists themselves admit in many occasions how the fascist ideology is essentially empty. When Mario teaches Accio the principles of fascism he asks 'do you know why you never betray the idea? Because the Idea is the Idea'. Later when the fascists go to visit Mussolini's grave stone the local leader explains the meaning of the fascist motto 'eja, eja ala la'. 'Do you know what it means?' he asks Accio, 'nothing... and yet everybody was behind him (Mussolini)'. Fascist ideology is demystified as an empty tautology.

The film suggests a similar critique of communism. The communist characters are far from being flawless: Manrico is self-centred and exhibitionist and for him militancy is a good way to attract girls, the political commitment of the two young female characters, Violetta and Francesca, is shallow and motivated by fashion and peer pressure. The leftist 
orchestra that plays a 'corrected' Marxist version of the Ode to Joy is a grotesque display of the communists' distance from reality. No ideology seems to provide a concrete answer to Accio's questions. He quits the Christian seminary because the priests are passive: they refuse to act against both the communists and his own sins. When Accio joins the MSI the fascist leader dismisses him and sends him to play table soccer. Similarly when Accio becomes a member of the radical left-wing movement he is told to wait. In some cases the political satire becomes overt comical gag like in the scene when a crack appears on the wall of the crumbling house. Accio fills the crack with the books by Marx and Lenin that he was reading in the toilet. The abstract tone of Accio's political reading is contrasted by the real problems that affect his household.

The two turning points of the movie are represented by the death of the two people who are the closest to Accio: Mario Nastri and Manrico. In both cases Accio is indirectly responsible for their deaths. In the first case Mario dies of heart attack in a fight caused by Accio. In the second Manrico is killed in an ambush of the police after Accio has given away the secret concerning their meeting place. Both events have a clear metaphorical meaning. Accio betrays Mario who is his spiritual father in the same way in which the Italians had betrayed their spiritual father Mussolini. In the second case Accio unwillingly collaborates with the police determining the end of Manrico in the same way in which the moderate left-wing had abandoned and marginalized the radical activists that were eventually crushed by the state repression. Accio represents the Italian people while the two other characters represent the two ideologies that have divided the country for 50 years, but were eventually destined to disappear. After both events Accio changes for the 
better. First, he gives up his futile political activism, later he finally finds his maturity when after Manrico's death he leads his family to a new home. The whole story can be interpreted as the relation of post-war Italy with ideology. The real villains in the film are ideologies, those abstract, obtuse mindsets that divide members of the same family or separate a house from their rightful owners. The reliance of Italians on abstract political symbols for 50 years did not bring any results, the death of ideologies is an occasion for Italians to mature and finally rely on their own means.

Hence, in the last 60 years Italian films have produced diverging discourses about neo-fascism. In the period that immediately followed the end of World War II, neofascism was virtually absent from Italian screens. When neo-fascists began to feature in Italian movies, during the 1950s and 1960s, they were often framed within a comical point of view and depicted as grotesque nostalgics of a regime that was irremediably confined to the past. The year 1969 and the beginning of the strategia della tensione represented a turning point in the representation of neo-fascism. The escalation of political violence that characterized the late 1970s implied that Italian film-makers tried at once to investigate and capitalize on the spectacular potential of the deviant and perverted actions of neo-fascist thugs. The period that follows 1989 and the collapse of communism is characterized by a new stage in the representation of neo-fascists. The films that deal with neo-fascism attempt to separate ideology from the personality of the characters. In these films neo-fascists are first and foremost victims of ideology, ordinary people who eventually pay the consequences of their erroneous political choices. 
Significantly, the last important film about neo-fascism, My Brother Is an Only Child, is set in the past, engaging in a process of historical revision that separates memory from ideology. While the film depicts the social, cultural and political conflicts that divided Italy during the 1960s and the 1970s through a metaphorical representation of the nation imagined as an unruly, dysfunctional family, it can tell us even more about how that record is considered in contemporary Italy, offering a new, post-ideological perspective on the events that led to the tragic season of political terrorism. The analysis of the representation of neo-fascism in contemporary Italian films such as My Brother Is an Only Child offers the opportunity to examine how the end of ideology and the lack of confidence in the old approaches to the conceptualization of Italian culture and society are leading to a redefinition of all contemporary Italian political cinema. 15

\section{References}

Accame, G. (1996), 'Proscritti in Patria', Area, December, p. 50.

Bisoni, C. (2009), Gli anni affollati. La cultura cinematografica italiana (1970-1979), Roma: Carocci.

Catanzaro, R. (1991), 'Subjective experience and objective reality: An account of violence in the words of its protagonists', in R. Catanzaro (ed.), The Red Brigades and Left-Wing Terrorism in Italy, London: Printers Publishers, pp. 174-203. 
Chiarini, R. (1995), Destra italiana. Dall'Unità d'Italia ad Alleanza Nazionale, Venezia: Marsilio.

Evola, J. (1998), Rivolta contro il mondo moderno, Roma: Edizioni Mediterranee.

Gregor, J. (2006), The Search for Neofascism: The Use and Abuse of Social Science, New York: Cambridge University Press, p. 54.

Fantoni Minnella, M. (2004), Non riconciliati. Politica e società nel cinema italiano dal neorealismo a oggi, Torino: Utet.

Forgacs, D. (1999), 'Days of Sodom: The fascism-perversion equation in films of the 1960s and 1970s', in R. J. B. Bosworth and P. Dogliani (eds), Italian Fascism: History, Memory and Representation, London: Macmillan, pp. 216-36.

Ginsborg, P. (1989), Storia d'Italia dal dopoguerra ad oggi. Società e politica: $1943-$ 1988, Torino: Einaudi.

Glynn, R., Lombardi, G. and O’Leary, A. (2010), 'Terrorism Italian style’, in R. Glynn, A. O'Leary, and G. Lombardo (eds), Terrorism, Italian Style: Representation of Political Violence in Contemporary Italian Cinema, London: IGRS, pp. 13-28. 
Gundle, S. (2000), Between Hollywood and Moscow: The Italian Communists and the Challenge of Mass Culture, 1943-1991, American Encounters/Global Interactions Durham: Duke University Press Books.

Ignazi, P. (2006), Extreme Right Parties in Europe, Oxford: Oxford University Press.

Miccichè, L. (1980), Il cinema italiano degli anni '60, Venezia: Marsilio.

O’Leary, A. (2008), 'Dead man walking: The Aldo Moro kidnap and Palimpsest history in Buongiorno notte', New Cinemas: Journal of Contemporary Film, 6:1, pp. 33-45. (2009), 'Moro, Brescia, Conspiracy: The paranoid style in Italian cinema', in P. Antonello and A. O'Leary (eds), Imagining Terrorism: The Rhetoric and Representation of Political Violence in Italy 1969-2009, Oxford: Legenda, pp. 48-62. (2010), 'Italian cinema and the "Anni di Piombo", Journal of European Studies, 40:3, pp. 243-57.

Pennacchi, A. (1993), Il fasciocomunista: vita scriteriata di Accio Benassi, Milano: Mondadori. 
Pergolari, A. (2007), 'La fisionomia del terrorismo nero nel cinema italiano degli anni ‘70’, in C. Uva (ed.), Schermi di Piombo, Soveria: Rubbettino, pp. 159-72.

Testa, C. (2006), 'Italian political cinema: Surveying a once glorious genre in times of anguish'anguish', Proceedings of Cornell Entralogos Conference 2005.

Wood, M. P. (2003), 'Revealing the hidden city: The cinematic conspiracy thriller of the ‘70s', The Italianist, 23, pp. 150-51.

_ (2010), 'Navigating the labyrinth: Cinematic investigations of right-wing terrorism', in R. Glynn, A. O’Leary and G. Lombardo (eds), Terrorism, Italian Style: Representation of Political Violence in Contemporary Italian Cinema, London: IGRS, pp. $29-44$.

Zagarrio, V. (2004), Cinema e Fascismo: Film, Modelli e Immaginari, Marsilio: Venezia. (2009), L’immagine del fascismo: la revisione del cinema e dei media nel regime, Roma: Bulzoni editore.

Zinni,M. (2010), Fascisti di celluloide. La memoria del ventennio nel cinema italiano (1945-2000), Venezia: Marsilio. 


\section{Contributor details}

Alfio Leotta teaches Film Studies at Victoria University of Wellington (New Zealand). He also taught Italian, European and Hollywood Cinema at both the University of Auckland and Massey University (Albany campus). His primary research interests focus on the relation between film and landscape, the history of the New Zealand film industry, Transnational Cinema and New Italian Cinema. He has recently published his first book monograph entitled Touring the Screen: Tourism and New Zealand FilmGeographies (Intellect Books, 2011).

\section{Contact:}

Alfio Leotta, Film Studies Programme, Victoria University of Wellington, 83 Fairlie Terrace, 6021 Wellington, New Zealand.

E-mail: alf.leotta@hotmail.fr

Notes

1The scope of the article will be limited to the analysis of films such as We Want the Colonels, The Children of Violent Rome, Skinheads and My Brother Is an Only Child that explicitly feature neo-fascist militants as main characters (see page 3 for a definition of neo-fascism).

2 The analysis of the representation of fascism in Italian cinema is beyond the scope of this work. Similarly this article will exclude the discussion of films about fascism such as 29 
Salò o le 120 giornate di Sodoma/Salò, or the 120 Days of Sodom (Pasolini, 1975), Una giornata particolare/A Special Day (Scola, 1977), Il sangue dei vinti/Blood of the Losers (Soavi, 2009) that resonate or indirectly refer to contemporary debates about neo-fascism. 3 Neo-fascism should be distinguished from post-fascism, a term that refers to the process of ideological revision accomplished by some neo-fascist movements that have abandoned totalitarian and anti-capitalist values and have established a dialogue with traditional, moderate right-wing parties. The difference between neo-fascism and postfascism is a fundamental issue in contemporary Italian political history; however, this article will only focus on the analysis of the relationship between contemporary Italian cinema and neo-fascism.

4Unless otherwise indicated, all translations from the original Italian are mine.

5 Partito Comunista Italiano/Italian Communist Party.

6 Democrazia Cristiana/Christian Democratic Party.

7This tendency was reflected in foreign policy too, particularly in the support of the Italian adhesion to the NATO and in the backing of Israel in the Middle East.

8 Evola was never a member of the National Fascist Party itself, and he regarded his position as that of a sympathetic right-wing intellectual, who saw potential in the movement and wished to guide or reform its errors through criticism. Evola's attitude towards Mussolini's regime highlights the fundamental ideological difference between fascism and neo-fascism. While fascism is characterized by political realism and in some 
cases opportunism, neo-fascism is influenced by a rigid and pessimist attitude towards the modern world.

9 The Tambroni Cabinet was the cabinet of the Government of Italy for only 123 days, from 25 March to 26 July 1960. Significantly, the government only got his necessary vote of confidence by the parliament, thanks to the votes of the MSI. It is often cited as the most reactionary government in Italy after Wold War II.

${ }_{10}$ Unless otherwise indicated, all translations from the original Italian are mine.

11The screenplay was prophetically written in 1967 and was originally inspired by the Greek coup d'état.

${ }_{12}$ We Want the Colonels is also interesting as it demonstrates the film-makers' difficulties in achieving production and distribution deals for films on right-wing terrorism. The film's distributor, Italnoleggio, lacked the resources for an in depth distribution and this contributed to the film's only moderate success in first-run cinemas (Della Casa cited in Wood 2010: 37).

13 The movie is based on a novel by Antonio Pennacchi, Il Fascio comunista (1993), which recounts the reasons that led its author to become first a neo-fascist and then a communist in 1960s Italy. The screenplay of the film, however, made some major changes to the novel adding new characters (such as the communist brother) and emphasizing the role of the family. 
14 In order to emphasize the fascist character of the town Luchetti shot the Latina sequences in other Italian towns that featured more typical examples of fascist architecture.

15 Luchetti's next film La nostra vita/Our Life (2010) is a good example of how in contemporary Italian cinema the old understanding of the proletariat as seen in the films of the 1960 s and 1970 s is completely put in question. 